International Journal of Instruction e-ISSN: 1308-1470 • www.e-iji.net
Received: 22/03/2018

Revision: 24/06/2018

Accepted: 28/06/2018

\title{
Culture of Traits in Arabic Language Education: Students' Perception of the Communicative Traits Model
}

\author{
Abdelaziz M. Hussien \\ Asst. Prof., Bahrain Teachers College, University of Bahrain, Sakheer, Bahrain; Faculty \\ of Education, Suez Canal University, Ismailia, Egypt, ahussien@uob.edu.bh
}

The purpose of the research reported in this article is to present the notion of Culture of Traits (CoTs) and to develop a 'Communicative Traits Model' (CTM) in teaching, learning, and assessing of Arabic as a first language. The ultimate goal is to create a shared vocabulary, establish a common language and build a consistent understanding of what constitutes good teaching, learning, and assessing of Arabic. Towards this aim, two complementary dimensions were investigated; An analysis of the origins and nature of the notion of CoTs, of how language learning happens and of how to conceptualize and encapsulate this in a model to create such a shared vocabulary in the teaching, learning, and assessing of Arabic. To validate the usefulness of CTM, the Bahraini teacher candidates completed the researcher-developed questionnaire to survey their views about what has been revealed by the analysis regarding CTM. Results indicated a very positive agreement on the importance of CTM as a clear and a practical framework to teach, learn, and assess the Arabic language not only in writing but also in speaking, reading and listening.

Keywords: culture of traits, communicative traits model, Arabic language education, language learning, learning

\section{INTRODUCTION}

The Culture of Traits (CoTs) term, in the current research, is inspired by two notions; the culture of learning (Cortazzi \& Jin, 1996) and the traits of a writing model (Culham, 2003, 2005, 2010). Cortazzi and Jin (1996) referred to the culture of learning as people's

expectations, attitudes, values, and beliefs about what constitutes good learning, about how to teach or learn, whether and how to ask questions, what textbooks are for, and how language teaching relates to broader issues of the nature and purpose of education (p. 169).

Citation: Hussien, A. M. (2018). Culture of Traits in Arabic Language Education: Students' Perception of the Communicative Traits Model. International Journal of Instruction, 11(4), 467-484. https://doi.org/10.12973/iji.2018.11429a 
Broadly speaking, stakeholders in the education sphered e.g., teachers, students, school principals, parents, curriculum developers, or policy makers, hold different and divergent expectations of what makes good teaching, learning and assessment. Some believe in the culture of memory and hence adopt surface and rote learning while others believe in the culture of creativity and then adopt deep learning and encourage students to participate and construct meaningful learning experiences (Biggs \& Tang, 2011; Marton \& Säljö, 1984). The critical point to be made here is whether there are common expectations among stakeholders in the language education of what makes good teaching, learning and assessment of the language, whether for example there are common understandings of who is a competent reader, writer, speaker or listener? Or in another way of formulating the same point whether there is a common understanding among teachers and students, for instance, of what good writing means, or what good reading entails, or what good speaking involves, or what good listening looks like?

Culham $(2003,2005,2010)$ approaches these questions with respect to writing in particular through a 'traits of writing model'. In her model, she intends to create a shared vocabulary, build a consistent understanding of common characteristics of what good writing is and what makes a good writer. She identifies seven traits that make good writing and enable a competent writer: ideas, organization, voice, word choice, sentence fluency, conventions, and presentation. This common understanding can then serve as a baseline for teaching, learning, and assessment of writing. In a large-scale five-year study on the traits of writing with fifth-grade teachers and students in 74 Oregon schools, Portland, results provided significant evidence of the effectiveness of using this 'traits of writing' analytical approach to improve students' writing with specific focus on the traits of organization, voice and word choice (Coe, Hanita, Nishioka, \& Smiley, 2011).

\section{CONTEXT OF TEACHING, LEARNING, AND ASSESSING OF ARABIC}

There is ample research investigating effective strategies and approaches in the teaching, learning, and assessing of Arabic (e.g., Abdelalbari, 2011a, 2011b, 2014; Younis, 2014). Most recently, Taha (2017) presented and advocated ten standards for the teaching and assessing of the Arabic language throughout school education k-12. Despite this effort, there is scant research on creating a shared vocabulary, common language, and consistent understanding in the teaching, learning, and assessing of Arabic across the Arab world. Talking about teaching, learning, and assessing of languages in general, it is crucial to have a framework of reference to guide all stakeholders (e.g., teachers, students, curriculum developers, or policy makers) in language teaching, learning, and assessment with respect of core language skills; writing, speaking, reading and listening (Council of Europe, 2018). This study addresses the issues which arise in the teaching, learning and assessing Standard Arabic due to its being a language used in numerous and varied education systems. The problems are lack of clarity and transparency among stakeholders e.g., students, teachers, or policy makers and that a framework - which is here offered as a model - can help better communication among professionals. The current study is addressing this paucity of research by providing and testing the notion of Culture of Traits (CoTs) (see Appendix A) that creates a shared 
vocabulary, establishes a common language and builds a consistent understanding of what constitutes good teaching, learning, and assessing of Arabic with respect to writing, speaking, reading, and listening. Creating such a shared vocabulary and a framework is intended to change peoples' expectations and to move teaching, learning, and assessing of Arabic from vagueness to specificity, from different approaches to a common ground, from scattered efforts to focus, and from vague language to a shared vocabulary.

\section{HOW LANGUAGE LEARNING HAPPENS}

There is no one grand theory that explains how language learning happens. Rather, language learning has been influenced by interdisciplinary fields, chief among them, linguistics, psychology, and sociology (Alexander \& Fox, 2013; Kern, 2000; Pearson \& Stephen, 1994). Since the 1950s, major changes and shifting paradigms in these fields have influenced and conceptualized different views of language learning.

From the linguistics perspective, language was seen as a perceptual process (Fries, 1962) or as a discrete set of skills and hence language teaching focused on developing knowledge of various language forms; phonological, morphological, lexical, syntactic, semantic, and pragmatic knowledge (Kern, 2000, p. 38). This view was influenced by Skinner's (1957) Behaviorism, the dominant theory of learning in the 1950s that emphasizes conditioned learning (i.e. stimulus-response). In the 1960s, Chomsky's Innateness Theory influenced the view of first language learning as a natural process where children have innate ability to acquire language (Chomsky, 1980). Chomsky's theory inspired the field of psycholinguistics (Pearson \& Stephens, p. 25). The psycholinguistic perspective shifted from viewing of language as a perception or a set of technical skills to focus on language as a process of thinking and of making meanings from genres (Smith \& Goodman, 1971). Further, it values using authentic genres that rely on natural language patterns and devalues using of simplified/artificial genres that rely on high-frequency words in simplified patterns (Pearson \& Stephens, 1994).

In the same direction, Cognitive Theory distinctly shifted the focus to how students learn and how minds work and process information (Neisser, 1967). Cognitive psychologists conceptualized language as a cognitive process where children process information and use their schema or prior knowledge to construct meanings from language genres. In practice, the cognitive perspective inspired language learning by focusing on two dimensions: schema-based learning and genre-based learning (Alexander \& Fox, 2013; Gaffney \& Anderson, 2000). On the one hand, a schema, mental representations of prior knowledge, plays a critical role in understanding new information stated in different types of language genres (e.g., Anderson, 2004; Bransford, 2004). On the other hand, explicit teaching of text structure improves understanding of language genres (e.g., Dymock, 2005; Meyer \& Rice, 1984). Above all, this cognitive dimension conceptualized language not only as a cognitive process but also as a meta-cognitive process that involves self-regulating, monitoring or evaluating understanding of different types of language genres (Flavel, 1979; Garner, 1987; Kern, 2000). Pearson and Stephens (1994, p. 32) argued that the cognitive perspective left an unanswered question that is where does the meaning reside? Is it in the child's mind or in the author's mind or 
in the text itself or in the interactions among them? This directs the discussion to focus on the sociolinguistic perspective.

In Social Interactionist Theory (Vygotsky, 1978), language is viewed as a social process where students understand and learn language through interactions in the classroom. Sociolinguistic is concerned with the interrelationships among language and social life and culture in a given context (Whitehead, 2004, p. 7). The burgeoning interest in social and cultural perspectives of language learning began in the middle of 1980s and on into 1990s (Alexander \& Fox, 2013; Gaffney \& Anderson, 2000). In fact, the sociolinguistic perspective is mostly influenced by Vygotsky (1978) and his colleagues, who drew attention to the importance of social interaction in students' development and learning. Unlike the psycholinguistic perspective, language, according to sociolinguists, is a social construct rather than a cognitive process (Street, 1994). In this context, Kern (2000) pointed out that "Literacy is variable and intimately tied to sociocultural practices of language use in a given society that is central in our teaching of language and culture" (p. 23). Above all, Street (1994) criticized linguists by presenting his ideological model in contrast with the autonomous model. According to the autonomous model, language is viewed as a set of neutral and universal technical skills taught through schools. On the contrary, according to the ideological standpoint, language is related to and sensitive of social and cultural practices in a given context. His ideological model "recognizes a multiplicity of literacy; that the meaning and uses of literacy practices are related to specific cultural contexts" (Street, 1994, p. 139). The practical point here is that the sociolinguistic perspective has a number of implications for language learning chief among them, it broadens the horizons of language learning to include not only factors in the classroom but also to involve the wider community (Pearson \& Stephens, 1994). Above all, it shifts attention to focus on communicative competence (Hymes, 1972) and how to use language to fit and achieve individuals' intentions and purposes in a given context.

Finally, the sociocognitive view is concerned with the interaction between linguistic, cognitive, and social perspectives of language learning (Gee, 2001; Pearson \& Stephens, 1994). It views language as a process of constructing meaning through interaction among teachers, students, and genres within the classroom context (Ruddell \& Unrau, 2004). To conclude, the study of language learning is a transdisciplinary or an interdisciplinary field (Alexander \& Fox, 2013; Pearson \& Stephen, 1994) and multiple facets process (Kern, 2000, p. 37) Although this interdisciplinary nature of language learning makes it richly research-informed field, it poses some challenges of creating a concrete framework and common language in teaching, learning, and assessing of a language (Dillon, O'Brien \& Heilman, 2013). The present study is an endeavour to establish such a concrete shared vocabulary in the teaching, learning and assessing of the Arabic language by presenting the notion of CoTs and developing a well researchinformed model, CTM (see Appendix A). In building this model, language is viewed as an analytic thinking process that has a concrete set of traits and characteristics where learners share and/or construct meanings from different types of genres to achieve their academic, social and personal purposes in a given context. 


\section{COMMUNICATIVE TRAITS MODEL}

CTM is a framework to create a common language by which learners communicate productively (i.e., writing and speaking) and/or receptively (i.e., reading and listening) using different types of language genres to achieve their purposes academically, socially and personally. The researcher presents a new model that visualizes the idea of the CoTs in the teaching, learning, and assessing of Arabic as a first language. It provides a clear and a specific framework that is inspired by the scientific research. It creates a shared vocabulary and a consistent understanding of what constitutes good teaching, learning, and assessing of Arabic with respect to core language processes; listening, reading, speaking and writing. Figure (1) illustrates this model, followed by an explanation of the scientific bases on which this model is developed.

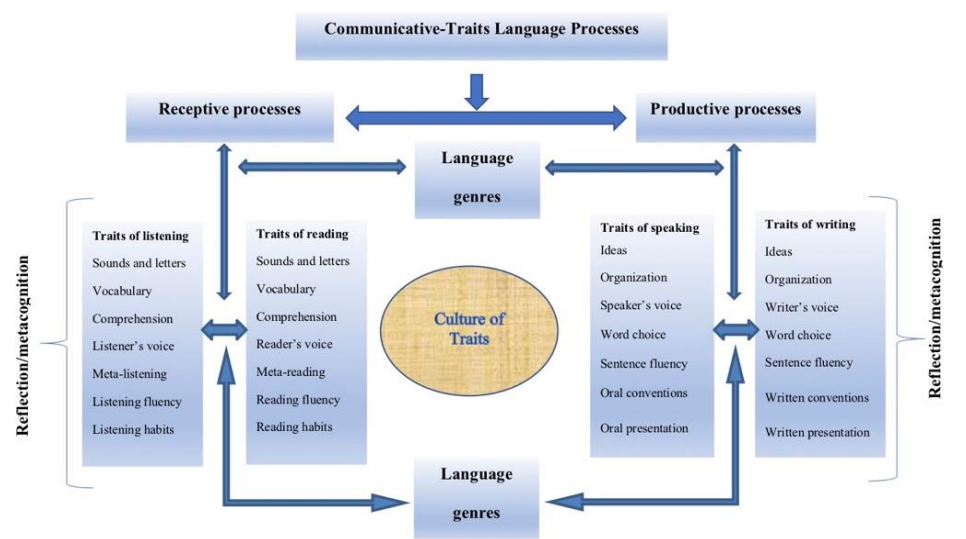

Figure 1

Communicative Traits Model

\section{Traits}

Traits are the core of the CTM. To identify the traits of Arabic language; writing, speaking, reading and listening, the researcher was inspired by the traits of writing model (Culham, 2003, 2005, 2010) and by the literature of teaching, learning, and assessing of the Arabic language (e.g., Abdelalbari, 2011a, 2011b, 2014; Taha, 2017; Younis, 2014). Each language process has seven traits (28 trait in total) and each trait has four characteristics (114 characteristic in total, the trait of ideas in writing and speaking has five characteristics) (see Appendix B), as is the case in the traits of writing model. These traits are more or less similar depending on whether they are productive or receptive. Precisely, writing and speaking traits are similar to productive processes and reading and listening are similar to receptive ones. This encapsulates these traits and creates a very concrete shared vocabulary that characterizes the teaching, learning, and assessing of the Arabic language. This is a summary of the traits of the Arabic language as presented in CTM. 


\section{Traits of writing involve}

Writing can be defined as the writer's voice and message to the reader using printed language genres to achieve her/his academic, social and personal purposes in a given context. Writing, as a productive process in the CTM, has seven traits as follows: (a) ideas, the writer's message to her/his reader/s, (b) organization, the internal design and structure of the written piece, (c) voice, the personal tone and flavour of the writer's message, (d) word choice, the vocabulary a writer chooses to convey meaning, (e) sentence fluency, the rhythm and flow of the written language, (f) conventions, the written mechanical correctness, and (g) presentation, the external design and structure of the written piece and how the writing looks on the page (Culham, 2003, 2005, 2010).

\section{Traits of speaking include}

Speaking can be defined as the speaker's voice and message to the listener/s using oral language genres to achieve her/his academic, social and personal purposes in a given context. As a productive process in the CTM, speaking has seven traits identified by the researcher as follows: (a) ideas, the speaker's message to her/his listener/s, (b) organization, the internet design of the oral speech, (c) voice, the personal tone and flavor of the speaker's message, (d) word choice, the vocabulary a speaker chooses to convey meaning, (e) sentence fluency, the rhythm and flow of the oral speech, (f) conventions, the oral mechanical correctness, and $(\mathrm{g})$ presentation, how the delivery of a speech looks like.

\section{Traits of reading entail}

Reading can be defined as the reader's voice and interaction to construct meanings and/or to generate ideas from printed language genres, and to benefit from this in her/his academic, social and personal life in a given context. As a receptive process in the CTM, reading has seven traits identified by the researcher as follows: (a) sounds and letters, alphabetical knowledge and phonological awareness of a language, (b) vocabulary recognition, discovering the forms and meanings of vocabulary, (c) reading comprehension, constructing the meaning and message of a printed texts, (d) reader's voice, reader's interaction with printed text and generating ideas in light of prior experiences, (e) reading fluency, the rate, accuracy and performance of the reader, (f) meta-reading, self-regulating and monitoring of the reader's own reading, and (g) reading habits, the way of setting, holding a book, eye movement and using technology to read.

\section{Traits of listening involve}

Listening can be defined as the listener's voice and interaction to construct meanings and/or to generate ideas from oral language genres, and to benefit from this in her/his academic, social and personal life in a given context. As a receptive process in the CTM, listening has seven traits identified by the researcher as follows: (a) sounds and letters, phonological awareness and alphabetical knowledge of a language, (b) vocabulary discrimination, discovering the sounds and meanings of vocabulary, (c) listening comprehension, constructing the meaning and message of oral texts, (d) 
listener's voice, listener's interaction with oral text and generating ideas in light of prior experiences, (e) listening fluency, the accuracy and pace of listening, (f) meta-listening, self-regulating and monitoring of the listener's own listening, and (g) listening habits, how to listen deliberately, follow up of the speaker and use technology to listen.

\section{Communicative Language Processes}

In the CTM, as a transactional communication model (Barnlund, 2008), students/communicators are simultaneously engaging in productive processes (i.e., writing and speaking) and/or receptive processes (i.e., reading and listening) to share or construct meanings using different types of language genres within a given social and cultural context. The CTM focuses on language as an 'analytic thinking process' rather than as a holistic product. In precise words, each productive or receptive process in the CTM is a thinking process that has three interrelated stages. For instance, writing is a thinking process that involves three sub-processes: pre-writing, composing, post-writing (Culham, 2010; Walshe, 2015). The traits weave into these stages, for example, the trait of ideas comes in the pre-writing stage, the trait of word choice stands out in the writing phase, and the trait of presentation falls in the post-writing stage (Culham, 2003, 2005, 2010).

\section{Communicative Competence}

The CTM supports the notion of 'communicative competence' (Hymes, 1972) This communicative competence involves many perspectives chief among them, the knowledge of language forms and how to use this knowledge to achieve different intentions and to fit different settings (Hedge, 2014). Traits and characteristics create a shared vocabulary that helps students to improve their communicative competence.

\section{Language Genre}

In the CTM, traits can be used to teach, learn and assess of different types of authentic genres productively and/or receptively. In the current context, genre-based approach (Derewianka, 2015; Johns, 2002) helps in creating a shared vocabulary and a common language that empower students to communicate effectively and to respond to their contexts using various types of genre knowledge.

\section{Reflective/Meta-cognitive Processes}

As a deep extension to language as an analytic thinking process, the Communicative Traits Model involves reflection or meta-cognitive processes (Flavel, 1979; Garner, 1987). Students reflect on and self-regulate their language learning. Reflection is one of the most important methods of developing performance and learning (Biggs \& Tang, 2011). It makes students aware of their strengths as well as the challenges they face, and then adjusting their learning in the desired direction.

Based on the critical analysis regarding the origins of the notion of the CoTs, how language learning happens, and the CTM, the present research sought to discover whether the claim that the CTM can help teachers establish a common understanding and use the model in practice. This was addressed by investigating how a group of 
trainee teachers would understand the CTM and its potential use. For a complete semester, those teacher candidates had the opportunity to study the traits of a writing model in teaching, learning, and assessing of Arabic for primary school children and thus they had good experience to validate the notion of CoTs and CTM.

\section{RESEARCH QUESTIONS}

This research investigated the answer to the main question: What is the Culture of Traits? Hence, it sought answers to the following sub-questions:

1. What are the views of Bahraini teacher candidates (Arabic specialization and class teacher) in the traits and characteristics of Arabic language processes; writing, speaking, reading and listening?

2. What are the views of Bahraini teacher candidates (Arabic specialization and class teacher) in the usefulness of CTM?

3. What is the difference among the views of Bahraini teacher candidates (Arabic specialization and class teacher) in the importance of CTM?

\section{METHOD}

\section{Research Design}

This research is a quantitative descriptive research. It advocates 'what ought to be' (Byram \& Feng, 2004, p. 150) in teaching, learning, and assessing of the Arabic language with respect to writing, speaking, reading and listening. To this aim, it surveyed and clarified the Bahraini teacher candidates' views on the importance of the notion of CoTs and CTM, after they studied traits of a writing model, proposed by the American educationalist, Ruth Culham, for a whole semester. The questionnaire was applied in a group face to face in the classroom at the end of the second semester in $2016 / 2017$ academic year, and the data was analyzed and discussed in light of the theoretical analysis and framework of research.

\section{Participants}

A purposeful sample of 93 Bahraini teacher candidates (10 males and 83 females) was selected. The sample consisted of the Arabic specialization candidates (31 participants; 7 males and 24 females), who teach Arabic language and Islamic studies for primary school children (grades 4-6) in Bahrain, and class teacher candidates (62 participants, 3 males and 59 females), who teach core subjects (e.g., Arabic language, Mathematics) for primary school children (grades 1-3) in Bahrain. The participants were enrolled in the second year of specialization (fourth in the college) at Bahrain Teachers College with an average age of 21 years. For a complete semester, the participants had the opportunity to study the traits of a writing model in teaching, learning, and assessing of Arabic for primary school children and thus they had good experience to validate the notion of CoTs and CTM.

\section{Questionnaire}

To examine the validity and usefulness of CTM as a framework that creates a shared vocabulary and a consistent understanding of what constitutes good teaching, learning, 
and assessing of the Arabic language with respect to writing, speaking, reading, and listening. A researcher-developed questionnaire (see Appendix C) was used where participants were requested to judge how important the statements are for them from on a five-point scale ranging very important to very unimportant. The participants ranked statements by importance on five dimensions: (a) traits of writing, (b) traits of speaking, (c) traits of reading, (d) traits of speaking, and (e) usefulness of CTM. To conclude, the questionnaire consists of 28 traits and 114 characteristics; it is divided into four language processes: writing ( 7 traits and 29 characteristics), speaking ( 7 traits and 29 characteristics), reading ( 7 traits and 28 characteristics) and listening (7 traits and 28 characteristics). In addition, there are 10 statements related to the use of traits model.

The validity of the questionnaire was verified by presenting it to some specialists to ascertain its clarity, face and content validity (i.e. it is designed to clarify the views of the participants on the Culture of Traits and Communicative Traits Model as a framework for teaching, learning, and assessing of the Arabic language). The internal consistency was verified using the Cronbach's alpha $=0.963$, which is a very high percentage that reflects high internal consistency of the questionnaire. The questionnaire was administered in a group face to face in the classroom where participants were requested to judge how important the traits and their characteristics and the use of traits model are for them from on a five-point scale ranging very important to very unimportant.

\section{Data Analysis}

The SPSS statistical package (version 20) was used to determine the importance of each trait and its characteristics of each language process as ranked by the participants. Kruskal Wallis H Test was used to clarify differences between the participants in Arabic specialization and class teacher candidates in their views on the usefulness of CTM as a framework for teaching, learning, and assessing of the Arabic language.

\section{FINDINGS}

This section presents data derived from the questionnaire. It explains the Bahraini teacher candidates' (Arabic specialization and class teacher) views on the importance of each trait and its characteristics and the use of traits in creating a common understanding in teaching, learning, and assessing of Arabic. Percentages were used to answer the first question, what are the views of Bahraini teacher candidates (Arabic language specialization and class teachers) in the traits and characteristics of Arabic language processes; writing, speaking, reading and listening? 
Table 1

Traits of writing, speaking, reading, and listening as ranked by the importance ( $N=93)$

\begin{tabular}{|c|c|c|c|c|}
\hline Processes & Traits & Positive response & $\begin{array}{l}\text { Negative } \\
\text { response }\end{array}$ & Rank \\
\hline \multirow[t]{8}{*}{ Writing } & Organization & $96 \%$ & $4 \%$ & 1 \\
\hline & Word choice & $95 \%$ & $5 \%$ & 2 \\
\hline & Sentence fluency & $94 \%$ & $6 \%$ & 2 \\
\hline & Ideas & $92 \%$ & $8 \%$ & 4 \\
\hline & Voice & $91 \%$ & $9 \%$ & 5 \\
\hline & Conventions & $88 \%$ & $12 \%$ & 6 \\
\hline & Presentation & $87 \%$ & $13 \%$ & 7 \\
\hline & Total Mean & $91.8 \%$ & $8.2 \%$ & \\
\hline \multirow[t]{8}{*}{ Speaking } & Word choice & $95.2 \%$ & $4.8 \%$ & 1 \\
\hline & Sentence fluency & $92.5 \%$ & $7.5 \%$ & 2 \\
\hline & Presentation & $92.5 \%$ & $7.5 \%$ & 3 \\
\hline & Organization & $91.7 \%$ & $8.3 \%$ & 4 \\
\hline & Ideas & $91.4 \%$ & $8.6 \%$ & 5 \\
\hline & Voice & $90.7 \%$ & $9.3 \%$ & 6 \\
\hline & Conventions & $85 \%$ & $15 \%$ & 7 \\
\hline & Total Mean & $91.3 \%$ & $8.7 \%$ & \\
\hline \multirow[t]{8}{*}{ Reading } & Reading comprehension & $94.2 \%$ & $5.8 \%$ & 1 \\
\hline & Reading fluency & $94 \%$ & $6 \%$ & 2 \\
\hline & Letters and Sounds & $93.7 \%$ & $6.3 \%$ & 3 \\
\hline & Vocabulary recognition & $92.5 \%$ & $7.5 \%$ & 4 \\
\hline & Reader's voice & $92 \%$ & $8 \%$ & 5 \\
\hline & Meta-reading & $88.7 \%$ & $11.3 \%$ & 6 \\
\hline & Reading habits & $86.5 \%$ & $13.5 \%$ & 7 \\
\hline & Total Mean & 91.6 & $8.4 \%$ & \\
\hline \multirow[t]{8}{*}{ Listening } & Listening habits & $95 \%$ & $5 \%$ & 1 \\
\hline & Sounds and Letters & $93.5 \%$ & $6.5 \%$ & 2 \\
\hline & Listening interaction & $92.5 \%$ & $7.5 \%$ & 3 \\
\hline & Word discrimination & $92.5 \%$ & $7.5 \%$ & 4 \\
\hline & Listening comprehension & $92.2 \%$ & $7.8 \%$ & 5 \\
\hline & Meta-listening & $88.2 \%$ & $11.8 \%$ & 6 \\
\hline & Listening fluency & $84 \%$ & $16 \%$ & 7 \\
\hline & Total Mean & $91 \%$ & $9 \%$ & \\
\hline
\end{tabular}

Table 1 explains the importance, as ranked by the participants, of the traits in teaching, learning, and assessing of Arabic with respect to writing, speaking, reading, and listening. The mean percentage of importance for the traits of each language processes was above $90 \%$ percent. This clearly implies to what extent the Bahrain teacher candidates, who studied the traits of a writing model, emphasize the value of using the traits not only in writing but also in speaking, reading and listening. Table 1 also indicates that all traits, across all language processes, were ranked with above $80 \%$ percent, as the lowest trait was 'listening fluency' with $84 \%$ percent of importance and the highest trait was 'organization of writing' with $96 \%$ percent. Priority can be given to 
traits that have a very high importance as ranked by the participants in curriculum design, teaching, learning and assessing of Arabic.

Percentages were also used to answer the second question, what are the views of Bahraini teacher candidates (Arabic specialization and class teacher) in the importance of CTM?

Table 2

Use of traits in teaching, learning and assessing of Arabic as ranked by the importance $(\mathrm{N}=93)$

\begin{tabular}{|c|c|c|c|}
\hline No & Items & $\begin{array}{l}\text { Positive } \\
\text { responses }\end{array}$ & $\begin{array}{l}\text { Negative } \\
\text { responses }\end{array}$ \\
\hline 1 & $\begin{array}{l}\text { Traits create a shared vocabulary in teaching and learning } \\
\text { of Arabic }\end{array}$ & $98 \%$ & $2 \%$ \\
\hline 2 & $\begin{array}{l}\text { Traits can be used to teach Arabic; writing, speaking, } \\
\text { reading and listening }\end{array}$ & $98 \%$ & $2 \%$ \\
\hline 3 & $\begin{array}{l}\text { Traits can be used to teach Arabic in different grades of } \\
\text { primary school. }\end{array}$ & $97 \%$ & $3 \%$ \\
\hline 4 & $\begin{array}{l}\text { Traits serve as a bassline to design teaching and learning } \\
\text { of Arabic }\end{array}$ & $96 \%$ & $4 \%$ \\
\hline 5 & $\begin{array}{l}\text { Traits serve as a bassline to design rubric for assessment } \\
\text { of Arabic }\end{array}$ & $96 \%$ & $4 \%$ \\
\hline 6 & $\begin{array}{l}\text { Traits is a process-focused approach rather than a product- } \\
\text { centered one }\end{array}$ & $95 \%$ & $5 \%$ \\
\hline 7 & $\begin{array}{l}\text { Traits help students to effectively communicate } \\
\text { productively (i.e., writing and speaking) and/or } \\
\text { receptively (i.e., reading and listening) }\end{array}$ & $94 \%$ & $6 \%$ \\
\hline 8 & $\begin{array}{l}\text { Traits have strong relations to Standards of Arabic } \\
\text { Education }\end{array}$ & $94 \%$ & $6 \%$ \\
\hline 9 & $\begin{array}{l}\text { Traits can be blended with the stages of language } \\
\text { processes }\end{array}$ & $92 \%$ & $8 \%$ \\
\hline 10 & Traits can be used to teach all types of language genres & $91 \%$ & $9 \%$ \\
\hline
\end{tabular}

Results of Table 2 show that the participants ranked all statements of the importance of CTM as a framework for teaching, learning and assessing of Arabic above $90 \%$ percent of importance. Table 2 also indicates that the first six statements got a rank of $95 \%$ and above which emphasizes the importance of CTM in creating a shared vocabulary and a common language in teaching, learning, and assessing of writing, speaking, reading, listening processes in different stages of education using different types of genres $(91 \%)$. Interestingly, results of Table 2 show that traits do not work independently rather they have strong relations to the standards of Arabic language education.

Kruskal Wallis H Test was used to answer the third question, what is the difference among the views of Bahraini teacher candidates (Arabic specialization and class teacher) in the importance of CTM? 
Table 3

Results of Kruskal-Wallis H Test between Arabic and class teacher candidates $(\mathrm{N}=93)$

\begin{tabular}{|c|c|c|c|c|c|c|}
\hline Variables & Specialization & No. & $\begin{array}{l}\text { Mean } \\
\text { Rank }\end{array}$ & $\chi^{2}$ & df & $\begin{array}{l}\text { Asymp. } \\
\text { Sig. }\end{array}$ \\
\hline \multirow{2}{*}{$\begin{array}{l}\text { Traits of } \\
\text { writing }\end{array}$} & Arabic teacher candidates & 31 & 40.82 & \multirow[t]{2}{*}{2.44} & \multirow[t]{2}{*}{1} & \multirow[t]{2}{*}{0.118} \\
\hline & Class teacher candidates & 62 & 50.09 & & & \\
\hline \multirow{2}{*}{$\begin{array}{l}\text { Traits of } \\
\text { speaking }\end{array}$} & Arabic teacher candidates & 31 & 43.05 & \multirow[t]{2}{*}{1.23} & \multirow[t]{2}{*}{1} & \multirow[t]{2}{*}{0.267} \\
\hline & Class teacher candidates & 62 & 49.69 & & & \\
\hline \multirow{2}{*}{$\begin{array}{l}\text { Traits of } \\
\text { reading }\end{array}$} & Arabic teacher candidates & 31 & 40.15 & \multirow[t]{2}{*}{3.01} & \multirow[t]{2}{*}{1} & \multirow[t]{2}{*}{0.083} \\
\hline & Class teacher candidates & 62 & 42.40 & & & \\
\hline \multirow{2}{*}{$\begin{array}{l}\text { Traits of } \\
\text { listening }\end{array}$} & Arabic teacher candidates & 31 & 42.40 & \multirow[t]{2}{*}{1.61} & \multirow[t]{2}{*}{1} & \multirow[t]{2}{*}{0.203} \\
\hline & Class teacher candidates & 62 & 50.01 & & & \\
\hline \multirow[t]{2}{*}{ All traits } & Arabic teacher candidates & 31 & 41.44 & \multirow[t]{2}{*}{1.68} & \multirow[t]{2}{*}{1} & \multirow[t]{2}{*}{0.195} \\
\hline & Class teacher candidates & 62 & 49.07 & & & \\
\hline \multirow{2}{*}{$\begin{array}{l}\text { Use of } \\
\text { traits }\end{array}$} & Arabic teacher candidates & 31 & 31.08 & \multirow[t]{2}{*}{17.09} & \multirow[t]{2}{*}{1} & \multirow[t]{2}{*}{0.000} \\
\hline & Class teacher candidates & 62 & 55.58 & & & \\
\hline
\end{tabular}

The results of the Kruskal Wallis $\mathrm{H}$ test show that there are no significant differences in the participants' responses regarding all traits of Arabic language (i.e., traits of writing, speaking, reading and listening), $\chi 2(1, N=93)=1.68, p=0.195$, with Mean Rank (41.44) for Arabic teacher candidates and Mean Rank (49.07) for class teacher candidates. On the other hand, there are significant differences between the responses of participants of the Arabic and class teacher candidates on the questionnaire in relation to the usefulness of CTM, $\chi 2(1, N=93)=17.09, p=0.000$, with Mean Rank (31.08) for Arabic teacher candidates and Mean Rank (55.58) for class teacher candidates.

\section{DISCUSSION}

\section{Establishing the Culture of Traits and Communicative Traits Model}

The present study was intended to establish and test empirically the notion of CoTs (see Appendix A) by presenting and examining clear expectations, a shared vocabulary, and a common language based on a set of traits and their characteristics that make good teaching, learning, and assessing of the Arabic language. This serves as a clear milestone and provides a consistent understanding among all those interested in the teaching, learning, and assessing of Arabic e.g., teachers, students, parents, curriculum developers or policy makers. It is very important to have a culture of learning or concrete and clear expectations of what constitutes good learning (Cortazzi \& Jin, 1996, p. 169). This is what has been approached by Culham $(2003,2005,2010)$ in her traits of writing model. She created a shared vocabulary that constitutes good writing and enables the component writer. To probe what constitutes good learning and what works effectively in teaching, learning, and assessing of Arabic, the researcher was inspired by research and practice in linguistics, psychology, sociology, and education. The current study came up with the notion of CoTs not only in writing but also in speaking, reading and listening. 
Theoretically, the investigator suggested and advocated CTM as a framework that explains how students use the traits to interact with language genres productively (i.e., in writing and speaking) and/or receptively (i.e., in reading and listening). Precisely, the shared vocabulary help students to create and share ideas while they write and speak and/or to construct meaning and generate ideas in light of their prior knowledge (e.g., Anderson, 2004; Bransford, 2004) while they read and/or listen. Having the shared vocabulary and common language provided by the traits, helps learners to visualize what constitutes good language learning either productively or receptively.

The key issue is that the present study came up with and advocated concrete ideas of what makes good teaching, learning, and assessing of Arabic, chief among them; traits, inspired by the traits of writing model (Culham, 2003, 2005, 2010). Each language process has seven traits (28 trait in total) and each trait has four characteristics (114 trait in total, the trait of ideas in writing and speaking has 5 characteristics) that characterize good language learning and enable competent writer, speaker, reader, and listener. In Communicative Traits Model, traits are apparently similar in writing and speaking as productive processes and in reading and listening as receptive processes. This makes these traits very concise and constitutes a concrete shared vocabulary in teaching, learning, and assessing of Arabic.

The argument is that traits as a shared vocabulary help learners to communicate productively and/or receptively where students use different types of genres (e.g., Derewianka, 2015) to produce and share ideas (in writing and speaking) and/or to construct and generate ideas (in reading and listening). In a certain context, students use knowledge of traits and genres to achieve their intentions academically, socially or personally. Above all, these traits weave into language as an analytic thinking process rather than a holistic product. Each language process has three stages and each stage involves some traits. Language is not only a process but also it involves reflection or meta-cognitive processes (Flavel, 1979; Garner, 1987). In a nutshell, language is a socio-cognitive process (Gee, 2001; Pearson \& Stephens, 1994) that has a concrete set of traits and characteristics where learners share and/or construct meanings from different types of genres to achieve their academic, social and personal purposes in each context.

\section{Examining the Culture of Traits and Communicative Traits Model}

The main finding of the empirical study is that the results of Table 2 showed the importance, as ranked by the participants, and usefulness of CTM in creating a shared vocabulary and common language for teaching, learning, and assessing of the Arabic language in different grades of primary school using different types of genres. This is congruent with what was explained by previous research on English language (Arter, Spandel, Culham, \& Polard, 1994; Coe, 2000; Coe et al., 2011). It unequivocally emphasized the importance of using such a model as a framework in teaching, learning, and assessing of Arabic not only in writing but also, in speaking, reading and listening. This implies practicality and timing of this proposition in teaching, learning, and assessing of the Arabic language. 
Interestingly, the results of Table 2 also showed that using traits do not work independently rather they have strong relations to the standards of Arabic language education (Taha, 2017, p. 30) and do not contradict language programs (Culham, 2005, p. 297). Traits support learning, teaching, and assessing of Arabic by simply creating the shared vocabulary and blending these traits into the writing, speaking, reading, and listening process. Despite this finding, the class teacher candidates were in a favour of using CTM than Arabic teacher candidates as explained in Table 3. This might be attributed to the approach by which they studied the traits of writing model. Studentcentred approach was used to teach class teacher candidates where they were required to do three main activities in studying each trait of writing; (a) prepare and present (in small groups) four activities to trigger the four characteristics of that trait, (b) develop a rubric for assessing children's writings in each trait, and (c) analyze and assess samples of children's writing using that rubric. It is a practical, concrete and engaging approach. On the contrary, Arabic teacher candidates were taught using the interactive lecture as the instructor provides information on each trait, challenges of teaching and learning this trait, and how to assess it. Students were mainly engaged in oral discussions and questioning.

The results of the descriptive statistics in Table 1 indicated that the total Mean score of traits in each language process got a rank above $90 \%$ percent of importance, which is a very high percentage indicating to what extent the research sample emphasized the importance of the traits. This refers to the practicality of these traits and it also implies that it is timely to use this shared vocabulary in teaching, learning, and assessing of the Arabic language. These results are consistent with what revealed about the importance of using traits in developing writing achievement in English language (Arter et al., 1994; Coe, 2000; Coe et al., 2011).

\section{CONCLUSION}

The Culture of Traits has taken its first steps. The researcher came up with the notion of CTM in teaching, learning, and assessing of Arabic with respect to writing, speaking, reading and listening. Inspired by previous research, he presented a specific number of traits (28 traits) and each trait has four characteristics (114 characteristic in total). These traits are similar in productive processes (i.e., writing and speaking) and in receptive processes (i.e., reading and listening) which makes these traits very concise and clear. He built his own CTM, which is inspired by the recent and well established scientific trends in language teaching and learning. Empirically, the researcher clarified the views of the Bahraini teacher candidates, who studied the traits of writing model, on his theoretical proposition. This resulted in emphasizing the importance and practicality of notion of using traits and CTM as a framework for teaching, learning, and assessing of Arabic with respect to writing, speaking, reading, and listening. This can inspire many fields, in theory and practice, including but not limited to teaching and learning of Arabic within the classroom, analytical assessment of Arabic, development of curricula for Arabic, and research in the field of teaching and learning of Arabic. But, the field still needs a lot of research, and experimentation, so that we enrich the idea and do it clearly and in a practical way in all stages of education in the Arab world. Future 
research and practice need to focus on the challenges and effectiveness of using traits in teaching, learning, and assessing of Arabic. Our slogan for the third decade of the twenty-first century in teaching, learning and assessing of Arabic, is "SAMAT" (i.e., traits in Arabic) that needs to be explicitly stated in our curricula, textbooks, teacher guides, curriculum documents, classroom walls, school corridors, conference brochures, meetings of teachers, directors, ministers, parents, social media, and among all stakeholders to spread this culture to better education not only for the Arabic language but also for the improvement of language education in general.

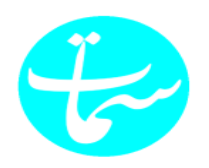

Figure 2

The slogan, SAMAT, traits in Arabic

\section{Acknowledgement}

My sincere gratitude goes to professor Mike Byram, University of Durham, for his constant support and guidance.

\section{REFERENCES}

Abdalbari, M. S. (2011a). مهارات التحدث: العملية والأداء [Speaking skills: Process and performance]. Amman: Dar Al Masirah for Publishing, Distribution and Printing.

Abdalbari, M. S. (2011b). مهارات الاستماع النشط [Active listening skills]. Amman: Dar Al Masirah for Publishing, Distribution and Printing.

Abdalbari, M. S. (2014). الكتابة الوظيفية والإبداعية [Functional and creative writing]. Amman: Dar Al Masirah for Publishing, Distribution and Printing.

Alexander, P. A. \& Fox, E. (2013). A historical perspective on reading research and practice. In D. E. Alvermann, N. J. Unrau, \& R. B. Ruddell (Eds.). Theoretical models and processes of reading ( $6^{\text {th }}$ ed., pp. 3-46). Newark, Delaware: International Reading Association.

Anderson, R. C. (2004). Role of the reader's schema in comprehension, learning, and memory. In R. B. Ruddell \& N. J. Unrau (Eds.). Theoretical models and processes of reading ( $5^{\text {th }}$ ed., pp. 594-606). Newark, Delaware: International Reading Association.

Arter, J., Spandel, V., Culham, R., \& Polard, J. (1994). The impact of training students to be self-assessors of writing. Paper presented at the Annual Meeting of the American Educational research association, New Orleans, LA. Retrieved 8 August, 2017 from https://files.eric.ed.gov/fulltext/ED370975.pdf 
Barnlund, D. C. (2008). A transactional model of communication. In. C. D. Mortensen (Eds.). Communication theory ( $2^{\text {nd }}$ ed., pp. 47-57). New Brunswick, New Jersey: Transaction.

Biggs, J. \& Tang, C. (2011). Teaching for quality learning at university (4 ${ }^{\text {th }}$ ed.). England: Society for Research into Higher Education \& Open University Press.

Bransford, J. D. (2004). Schema activation and schema acquisition: Comments on Richard C. Anderson's remarks. In R. B. Ruddell \& N. J. Unrau (Eds.). Theoretical models and processes of reading ( $5^{\text {th }}$ ed., pp. 607-619). Newark, Delaware: International Reading Association.

Byram, M. \& Feng, A. (2004). Culture and language learning: teaching, research and scholarship. $\quad$ Language Teaching, $\quad 37(3), \quad 149-168$. https://doi.org/10.1017/S0261444804002289

Chomsky, N. (1980). Rules and representations. New York: Columbia University Press.

Coe, M. T. (2000). Direct writing assessment in action: Correspondence of six-trait writing assessment scores and performance on an analog to the Washington assessment of student learning writing test. Portland, OR: Northwest Regional Educational Laboratory.

Coe, M. T., Hanita, M., Nishioka, V., \& Smiley, R. (2011). An investigation of the impact of the $6+1$ trait writing model on grade 5 student writing achievement, final report. U.S. Department of Education: Institute of Education Sciences. Retrieved 10 October, 2017 from http://files.eric.ed.gov/fulltext/ED527445.pdf

Cortazzi, M \& Jin, L. (1996). Cultures of learning: Language classrooms in China. In H. Coleman (Ed.). Society and the language classroom (pp. 169-206). London: Cambridge University Press.

Culham, R. (2003). 6+1 traits of writing: The complete guide, grades 3 and up. New York: Scholastic Inc.

Culham, R. (2005). 6+1 traits of writing: The complete guide for the primary grades. New York: Scholastic Inc.

Culham, R. (2010). Traits of writing: The complete guide for middle school. New York: Scholastic Inc.

Council of Europe (2018). Common European framework of reference for languages: Leaning, teaching, assessment: Companion volume with new descriptors. Retrieved 20 February, 2018 from https://www.coe.int/en/web/common-european-frameworkreference-languages.

Derewianka, B. (2015). The contribution of genre theory to literacy education in Australia. In J. Turbill, G. Barton, \& C. Brock (Eds.). Teaching writing in today's classroom: Look back to look forward (pp 69-86). Norwood: Australian Literacy Educators' Association. 
Dillon, D. R., O'Brien, D. G., \& Heilman, E. E. (2013). Literacy research in $21^{\text {st }}$ century: From paradigms to pragmatism and practicality. In D. E. Alvermann, N. J. Unrau \& R. B. Ruddell (Eds.). Theoretical models and processes of reading $\left(6^{\text {th }}\right.$ ed., pp. 1104-1132). Newark, Delaware: International Reading Association

Dymock, S. J. (2005). Teaching expository text structure awareness. The Reading Teacher, 59(2), 177-182. doi: 10.1598/RT.59.2.7.

Flavel, J. H. (1979). Metacognition and cognitive monitoring: A new area of cognitivedevelopmental inquiry. American Psychologist, 34(10), 906-911. http://dx.doi.org/10.1037/0003-066X.34.10.906

Fries, C. C. (1962). Linguistics and reading. New York: Holt, Rinehart \& Winston.

Gaffney, J. S. \& Anderson, R. C. (2000). Trends in reading research in the United States: Changing intellectual currents over three decades. In M. L. Kamil et al. (Eds.). Handbook of reading research (Vol. III, pp. 53-74). New Jersey: Lawrence Erlbaum Associates.

Garner, R. (1987). Metacognition and reading comprehension. New Jersey: Ablex Publishing Corporation.

Gee, J. P. (2001). Reading as situated language: A sociocognitive perspective. Journal of Adolescent \& Adult Literacy, 44 (8),714-725. doi: 10.1598/JAAL.44.8.3

Hedge, T. (2014). Teaching and learning in the language classroom. Oxford: oxford University Press.

Hymes, D. (1972). On communicative competence. In J. B. Pride \& J. Holmes (Eds.), Sociolinguistics (pp. 269-293). UK: Penguin.

Johns, A. M. (Ed.) (2002). Genre in the classroom: Multiple perspectives. Mahwah, NJ: Lawrence Erlbaum.

Kern, R. (2000). Literacy and language teaching. London: Oxford University Press.

Marton, F. \& Säljö, R. (1984). Approaches to learning. In F. Marton, D. Hounsell, \& N. Entwistle (Eds.). The experience of learning (pp. 36-55). Edinburgh: Scottish Academic Press.

Meyer, B. J. F. \& Rice, G. E. (1984). The structure of text. In P. D. Pearson (Ed.). Handbook of reading research (Vol. I, pp. 319-352). New York: Longman.

Neisser, U. (1967). Cognitive psychology. New York: Appleton-Century-Crofts

Pearson, P. D. \& Stephens, D. (1994). Learning about literacy: A 30-year journey. In R. B. Ruddell, M. R. Ruddell, \& H. Singer (Eds.). Theoretical models and processes of reading ( ${ }^{\text {th }}$ ed., pp. 22-42). Newark, Delaware: International Reading Association.

Ruddell, R. B. \& Unrau, N. J. (2004). Reading as a meaning-construction process: The reader, the text, and the teacher. In R. B. Ruddell \& N. J. Unrau (Eds.). Theoretical 
models and processes of reading (5 ${ }^{\text {th }}$ ed., pp. 1462-1521). Newark, Delaware: International Reading Association.

Skinner, B. F. (1957). Verbal behavior. New York: Appleton-Century-Crofts.

Smith, F. \& Goodman, K. S. (1971). On the psycholinguistic method of teaching reading. Elementary School Journal, 71(4), 177-181. http://www.jstor.org/stable/1000548

Street, B. V. (1994). Cross-cultural perspectives on literacy. In J. Maybin (Ed.). Language and literacy in social practice (pp. 139-150). Clevedon, Philadelphia: Multingual Matters Ltd. in Association with the Open University.

Taha, H. (2017). معايير فنون اللغة العربية (المستوى الآول- المستوى الرابع) (طץ) [Arabic language standards (level 1 - level 4) (2 ${ }^{\text {nd }}$ ed.)]. Dammam: Dar Al-Kitab Al-Tarbawi for publishing and distribution.

Vygotsky, L. S. (1978). Mind in society: The development of higher psychological processes. Cambridge, MA: Harvard University Press.

Walshe, R. D. (2015). Writing as process. In J. Turbill, G. Barton, \& C. Brock (Eds.). Teaching writing in today's classroom: Look back to look forward ( $\mathrm{pp}$ 13-25). Norwood: Australian Literacy Educators' Association.

Whitehead, M. R. (2004). Language and literacy in the early years ( $3^{\text {rd }}$ ed.). London: SAGE.

Younis, F. (2014). اتجاهات حديثة وقضايا أساسية في تعليم القراءة وبناء المنهج [Recent trends and key issues in teaching reading and curriculum design]. Cairo: Wahba Library. 